\title{
Imaging findings of pseudomesothelioma cases resulting from two different primary tumours
}

\author{
IşıI BAŞARA AKIN ${ }^{1}$ \\ Canan ALTAY ${ }^{1}$ \\ PInar BALCI ${ }^{1}$
}

\footnotetext{
${ }^{1}$ Department of Radiology, Faculty of Medicine, Dokuz Eylul University, Izmir, Turkey

${ }^{1}$ Dokuz Eylül Üniversitesi Tıp Fakültesi, Radyoloji Anabilim Dalı, İzmir, Türkiye
}

\section{SUMMARY}

Imaging findings of pseudomesothelioma cases resulting from two different primary tumours

Pleural metastases mimic malignant mesothelioma result from rare tumours. The most common tumour that metastase to pleura is primary bronchogenic adenocarcinoma. Other primary lung tumours rarely matastase to pleura. Although lung is the most common site for renal cell carcinoma (RCC) metastases, pleural effusion and pleural matestases resulting pseudomesothelioma is very rare. Herein we report two cases of pseudomesothelioma resulting from small cell carcinoma and RCC.

Key words: Pseudomesothelioma, renal cell carcinoma, small cell carcinoma

\section{ÖZET}

iki farklı primer tümörden kaynaklanan psödomezotelyoma olgularının görüntüleme bulguları

Malign mezotelyomayı taklit eden plevral metastaz nadir tümörlerden kaynaklanır. Plevraya metastaz yapan en sık tümör primer bronkojenik adenokarsinomdur. Diğer primer akciğer tümörleri nadiren plevraya metastaz yapar. Renal hücreli karsinom (RHK) en sık akciğere metastaz yapmasına ragmen plevral efüzyon ve psödomezotelyoma ile sonuçlanan plevral metastaz oldukça nadirdir. Bu yazıda, küçük hücreli akciğer karsinomu ve RHK'dan kaynaklanan iki farklı psödomezotelyoma olgusunu sunuyoruz.

Anahtar kelimeler: Psödomezotelyoma, renal hücreli karsinom, küçük hücreli karsinom

A 47-year-old male patient was admitted to chest disease out-patient clinic with the chief symptoms of cough, dyspnoea, weakness and weight loss. First, the patient was detected with posterior anterior chest radiography examination (Figure 1A). The patient was redirected for further radiologic and nuclear medicine evaluations with pre-diagnosis of primary pleural mesothelioma (Figure $1 \mathrm{~B}, \mathrm{C})$. After these evaluations radiologic and nuclear medicine findings were confirmed the diagnosis as primary pleural mesothelioma. For oncologic medical treatment, biopsy was performed and the patient was diagnosed as small cell lung carcinoma (SCLC).

\section{Yazışma Adresi (Address for Correspondence)}

Dr. Işıl BAŞARA AKIN

Dokuz Eylül Üniversitesi Tıp Fakültesi,

Radyoloji Anabilim Dalı, IZMIR - TURKEY

e-mail: isilbasara@gmail.com 


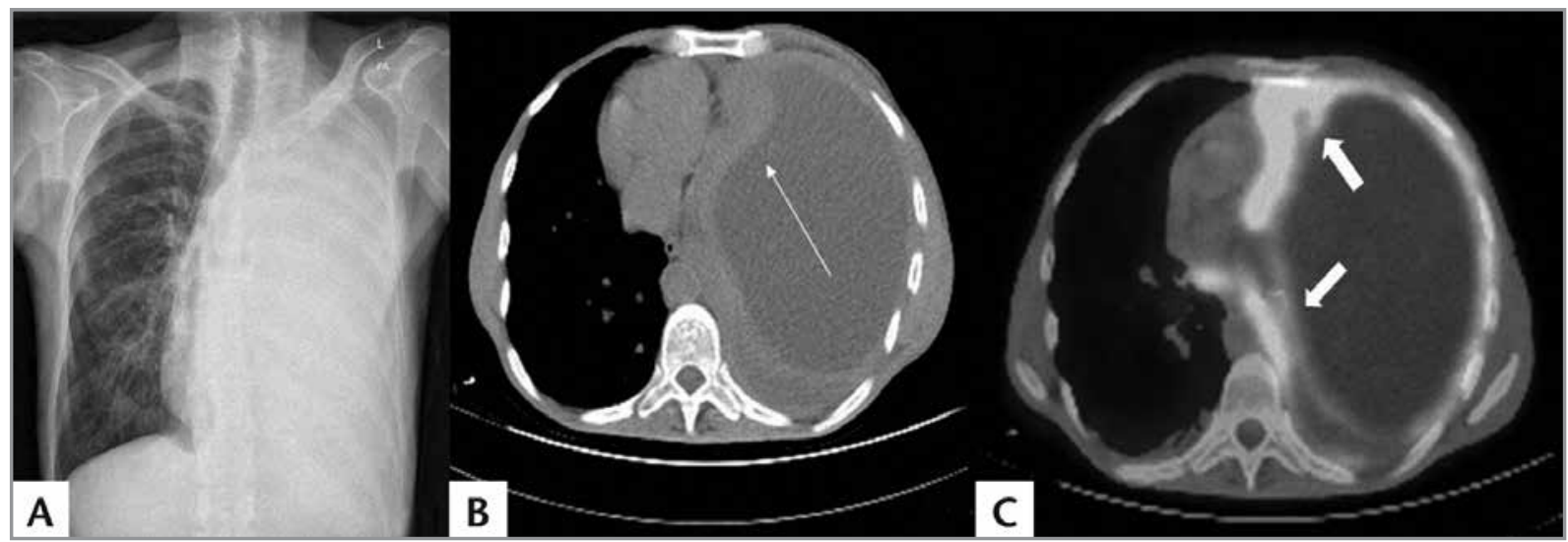

Figure 1. (A) In chest radiography there is loss of left lung ventilation, (B) in computed tomography (CT) image, there are diffuse pleural thickening and massive effusion (thin arrows), (C) in positron emission tomography (PET) image, there is diffuse signal increase due to florodeoksiglukoz (FDG) uptake (thick arrows).

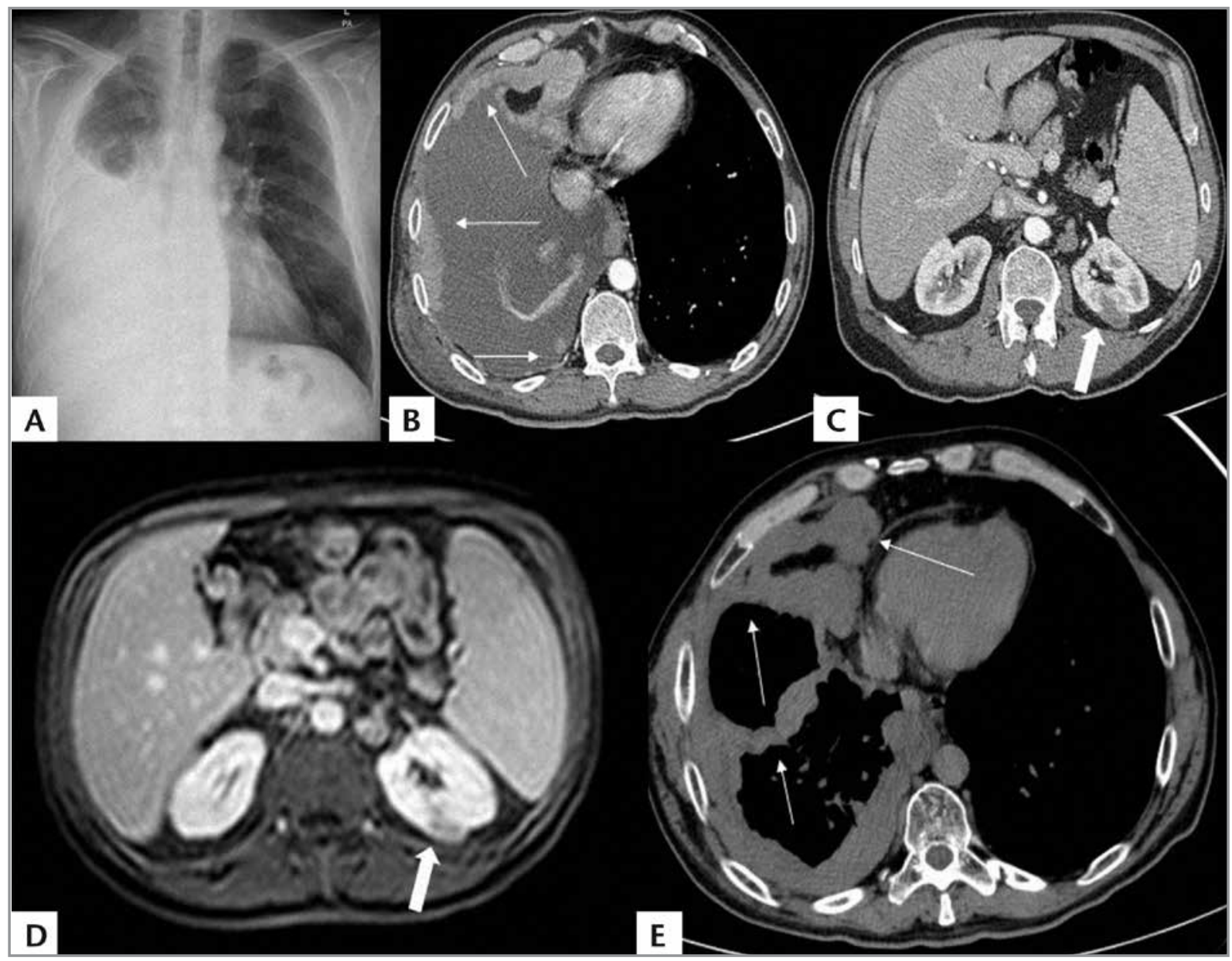

Figure 2. (A) In chest radiography, there is right costophrenic sinus angle blunting and loss of middle-lower zone ventilation, (B) in CT examination, there are diffuse nodular pleural thickening (thin arrows), enhancement and massive effusion, (C) additionally, there is a suspicious lesion at the middle part of his left kidney (thick arrow), (D) in MRI evaluation, there is lesion enhancement in the left kidney (thick arrow), (E) in CT examination, there is an increase in nodular pleural thickening (thin arrows). 
A 54-year-old male patient was admitted to chest disease out-patient clinic with similar symptoms of the first case. The patient was evaluated with chest radiography, CT (Figure 2A,B,C). Pleural findings was thought as primary mesothelioma however the patient was detected with magnetic resonance imaging (MRI) for evaluation of left kidney lesion (Figure 2D). The lesion was diagnosed as a suspicious malignant lesion. The patient was first redirected to pleural biopsy and after nephrectomy. Nephrectomy material was diagnosed as renal cell carcinoma (RCC) and pleural biopsy was concluded as RCC metastasis. After operation the patient was put in medical oncologic treatment procedure, in follow up process there was a progress of pleural metastases (Figure 2E).

Diffuse pleural metastases and mass encasement radiologically mimic malignant mesothelioma, result from rare tumours. The term 'pseudomesothelioma' was first described by Harwood et al. for distinctive diffuse pleural metastasis of bronchogenic adenocarcinoma. The most frequent tumours which causes pseudomesothelioma is primary adenocarcinoma. However, other histological subtypes of primary lung carcinomas have also been described (1). These tumours, especially peripheral lung adenocarcinoma and other subtypes of primary lung carcinomas directly and extensively invade the pleura (2).
Although the lung is the most commonsite of metastasis of RCC, pleural effusion and pleural metastasis without lung lesions are rarely the initial presenting problems. Pleural metastasis due to RCC occurs due to haematogenous spread to the pleura via the renal veins and inferior vena cava. Another route of pleural metastasis is through Batson's plexus which has extensive anastomoses to the azygos, hemiazygos, lumbar, bronchial and intercostal vein (3).

In conclusion, pleural 'pseudomesotheliomatous' carcinomas are uncommonand represent a pathologically heterogeneous group oftumours with poor prognosis. Although radiologic findings of tumours refers primary mesothelioma of pleura, tissue diagnosis should be obtained in all cases of suspected diffuse pleuralneoplasia.

\section{REFERENCES}

1. Attanoos RL, Gibbs AR. 'Pseudomesotheliomas' carcinoma of the pleura; a 10-year analysis of cases from the Environmental Lung Disease Research Group. Cardiff Histopathology 2003;43:444-52.

2. Tang $P$, Vatsia SK, Teichberg S, Kahn E. Pulmonary adenocarcinomasimulating malignant mesothelioma. Arch Pathol Lab Med 2001;125;1598-1600.

3. Kutty K, Varkey B. Incidence and distribution ofintrathoracic metastases from renal cell carcinoma. Arch Intern Med 1984; 144:273-6. 